\title{
Changes in Preschool Childcare and Private Education Expenses of Different Income Groups Caused by the Expansion of the Childcare Subsidy Recipients: A Focus on Universal Childcare Policy
}

\author{
Su-Ji Jung ${ }^{1}$, Yun-Hyun Pack ${ }^{2}$, Ji-Na Song ${ }^{1}$, Daewoong Kim ${ }^{1}$, Soon-Hyung Yi ${ }^{1,3}$ \\ Department of Child Development and Family Studies, Seoul National University, Seoul, Korea ${ }^{1}$ \\ Interdisciplinary Program in Early Childhood Education, Seoul National University, Seoul, Korea ${ }^{2}$ \\ Research Institute of Human Ecology, Seoul National University, Seoul, Korea ${ }^{3}$ \\ 보육비 지원대상 확대에 따른 소득계층별 유아 보육비 및 사교육비 변화: \\ 무상보육정책 시행을 중심으로 \\ 정수지 ${ }^{1}$, 박윤현 ${ }^{2}$, 송지나 ${ }^{1}$, 김대웅 ${ }^{1}$, 이순형 ${ }^{1,3}$ \\ 서울대학교 아동가족학과, 서울대학교 사범대학 협동과정 유아교육전공', 서울대학교 생활과학연구소 ${ }^{3}$
}

Objective: The purpose of this study was to examine the changes of childcare expenses and private education expenses caused by target expanding the childcare subsidy policy and its relationship to household income.

Methods: The study analyzed data of the Korean Welfare Panel Study from 2009, before the universal childcare policy was enforced, to 2013, when the universal childcare policy was enforced.

Results and Conclusion: The results of analysis were as follows. First, while childcare expenses, private education expenses, and their ratios to household income showed a tendency of gradual decline, the graphs of childcare and private education expenses were symmetric. Second, there were differences in childcare and private education expenses among income classes. Third, in 2009, before the universal childcare policy was enforced, household income affected childcare and private expenses. Lastly, in 2013, after the universal childcare policy was implemented, household income had a greater effect on private education expenses, while the effect of household income on childcare expenses became insignificant.

Keywords: preschool childcare expenses, preschool private education expenses, universal childcare policy, income groups, childcare expenses subsidy

\footnotetext{
서론

저출산 및 고령화 현상과 같은 신 사회위험(new social risks)에

Corresponding Author: Soon-Hyung Yi, Department of Child Development and Family Studies, Seoul National University, 1 Kwanak-gu, Seoul 151742, Republic of Korea

E-mail: ysh@snu.ac.kr
}

대한 대처로서, 전 세계적으로 영유아 보육은 주요한 사회 이 슈로 떠오르고 있다(Castles, 2010). 우리나라는 1970년대까지 는 1970년 4.53명, 1975년 3.43명, 1979년 2.90명으로 비교적

(C)The Korean Association of Child Studies

This is an Open Access article distributed under the terms of the Creative Commons Attribution Non-Commercial License (http:// creativecommons.org/licenses/by-nc/4.0) which permits unrestricted noncommercial use, distribution, and reproduction in any medium, provided the original work is properly cited. 
높은 수준의 합계출산율을 유지하였다. 그러나 1983년에 출 산율이 대체출산율 이하 수준인 2.06명으로 급격하게 하락하 였으며, 이후 2005년에는 1.08명, 2010년에는 1.23명, 2014년 에는 1.21 명을 기록하여 $\mathrm{OECD}$ 의 초저출산의 기준인 1.30 명 에 미치지 못하는 낮은 수준을 유지하고 있다(Statistics Korea, 2015a). 급격한 출산율 저하의 주요한 원인으로는 고용불안 정, 여성 취업 증가로 인한 결혼 및 출산에 대한 기피, 과도한 양육비와 교육비 부담이 지적되었다. 이에 따라 결혼 및 출산 에 대한 부담을 완화시킬 수 있는 정부의 대안을 요구하는 목 소리가 높아져 갔으며, 가정의 양육부담 완화를 위하여 아동 보육에 대한 국가의 책임을 강화해야 한다는 사회적 논의가 진행되기 시작하였다.

이에 따라 정부의 보육비 지원 대상범위가 점차 확대되어 왔다. 저소득층 아동에 대한 보육비 지원은 1992년부터 시작 되었으며, 2006년부터 차상위계층을 대상으로 보육비 전액 지원이 시작되었다(Ministry of Health and Welfare [MOHW], 2013). 정치권에서도 2000년대 이후 무상보육정책이 선거공 약으로 등장하며 이슈화되기 시작하였으며, 이후 2010년 여 권과 야권이 경쟁적으로 복지정책 이슈화를 주도하면서, 자 녀양육비 부담 감소를 위한 무상보육정책이 본격적으로 추진 되었다. 그 결과 2011년 11월에 5세 누리과정이 실시되었고, 2013년 3월부터 5세 이하 아동을 대상으로 보육비를 지원하 는 무상보육정책이 실시되었다. 무상보육정책이란 보건복지 부에서 실시하는 0-5세 보육비 지원사업으로, 소득에 관계없 이 전 계층을 대상으로 어린이집 이용 영유아의 보육비를 지 원하고, 어린이집을 이용하지 않는 경우 양육수당을 지급하여 부모의 자녀양육 부담경감 및 원활한 경제활동 지원하는 보육 및 교육비 지원 정책이다(J. S. Kim, 2014).

보육-교육시설은 영유아에게 매우 중요한 발달 맥락으로 (Branscomb \& Goble, 2011) 무상보육정책 시행으로 영유아의 보육·교육시설 이용이 증가하여 영유아 발달에도 광범위한 변 화가 나타날 것으로 예상된다. 그러나 무상보육정책 시행으로 기대되는 일차적이며 가장 주요한 효과는 가구의 영유아 보 육비 및 교육비 절감에 있다고 할 수 있다(K. I. Kim, 2014). 정 부의 보육비 및 양육비 지원이 전 계층으로 확대되면서, 보육 비 지출 경감 혜택을 받는 가구도 크게 증가해왔다. 보건복지 부의 아동종합실태조사에 따르면 무상보육정책이 실시되면 서, 5 세의 경우 어린이집 및 유치원 이용률이 지난 3 년간 $71 \%$, $82 \%, 96 \%$ 로 증가하였고 3세의 경우도 $87 \%, 86 \%, 93 \%$ 로 증 가하는 추세를 보였다(M. S. Kim et al., 2013).

정부의 보육비 지원이 확대되어감에 따라, 무상보육정책
실시 이전부터 보육비 지원 정책의 효과 분석과 가구의 보육 비 지출 변화에 대한 연구들이 많이 진행되었다. 보육비 지출 의 경제적 효과를 살펴볼 때, 2008년에서 2012년까지 가구의 보육비 지출을 분석한 연구에서는 정부의 보육료 지원확대가 가구의 실질적 보육비 부담을 감소시킨 것으로 나타났으며(K. I. Kim, 2014), 5세 누리과정 도입 후 가구의 교육·보육비 지출 총액이 절감된 것으로 나타났다(Y. J. Lee, Lee, \& Kim, 2013). 보육비 지원 만족도에 대한 연구에서는 시설장, 보육교사, 학 부모 중에서 학부모의 만족도가 가장 높은 것으로 나타났으며 시설장, 보육교사, 학부모 모두 보육비 지원이 보육비 부담 경 감효과가 있다고 응답한 것으로 나타났다(Jung, 2012). 이처럼 다수의 연구를 통해 보육비와 양육비 지원 정책이 영유아 가 구의 보육비 지출 부담, 더 나아가 자녀양육비 부담을 경감시 켰다는 것이 확인되었다(S. H. Kim, Joo, \& Hong, 2013). 그러 나 선행연구에서는 무상보육 시행 시점인 2013년 시기를 포 괄하지 못했기 때문에 무상보육정책의 효과를 실제적으로 확 인하기 어렵다는 한계가 있다. 따라서 이 연구에서는 무상보 육정책의 효과를 살펴보기 위해 무상보육정책 실시 전후 보 육·교육비 변화 경향성을 살펴보고자 하였다.

또한 실제 무상보육정책의 효과를 평가하기 위해서는, 보 육비뿐만 아니라 사교육비도 함께 고려할 필요성이 있다. 이 는 여러 선행연구에서 보육 및 교육에 대한 정부 지원금이 사 교육에 재투자되는 현상을 보고해왔기 때문이다(Suh, Yang, \& Son, 2012). 선행연구에 따르면 보육비 지원이 사교육을 시 작하는 계기가 되며(Min \& Bae, 2014), 보육비 지원 확대 후에 오히려 사교육비가 증가하는 경향이 나타난 것으로 밝혀졌다 (Yang, 2013). Y. J. Lee 등(2013)은 고소득층 및 대도시 거주 가 구는 보육 및 교육비 지원을 받음으로써 사교육 이용이 증가 될 가능성이 있다고 보고하였고, 한국교육개발원의 조사에서 도 응답자의 $65 \%$ 가 경제적 여유가 생긴다면 사교육 지출을 늘리겠다고 응답한 것으로 나타났다(Cha et al., 2010). 즉, 이러 한 결과는 사교육비의 경우 가구의 가처분소득에 따른 지출액 유동성이 크다는 것을 의미하며, 국가의 영유아 보육비지원이 가구의 사교육비 부담을 증가시킬 가능성이 있다는 것을 시사 한다. 따라서 무상보육정책 시행 전후에 보육비와 사교육비의 변화 추세를 비교하고, 가구소득이 보육비 및 사교육비 지출 에 미치는 영향력이 달라지는지 비교분석할 필요성이 있다.

선행연구에서 우리나라 가구의 유아 사교육 이용 비율은 매우 높은 수준이며, 사교육비 부담액도 큰 것으로 나타났다. 3 세 이상 유아 가구 2,527 가구를 분석한 연구에서는 유아 사 교육 참여율이 $99.8 \%$ 로 나타났으며 유아 부모 $74.3 \%$ 가 유아 
교육비에 부담을 느낀다고 보고하였다(Cha et al., 2010). 한국 노동패널조사 자료를 분석한 Kwon (2011)은 유아의 사교육 이용률은 $74.5 \%$ 이며, 전체 유아를 모수로 하였을 경우 평균 지출 금액은 227,400 원, 사교육을 이용하는 유아만을 모수로 하였을 경우 평균 지출 금액은 305,200 원이라고 보고하였다. 이처럼 과중한 유아 사교육비 지출 부담에 대한 관심이 필요 한 시점에서, 보육비 지원 정책의 효과로 인해 나타나는 사교 육비 변화경향을 살펴보는 것은 의미를 지닌다 할 수 있다.

또한 무상보육정책은 부모의 소득 계층과 무관하게 보육비 를 지원해주고, 모든 영유아에게 표준화된 공통의 보육과정 을 제공한다는 점에서 소득재분배 효과를 가지는 것으로 평가 된다. 그러나 가구소득분위별로 무상복지정책 및 보육비 지원 정책의 효과를 분석한 선행연구에서 그 효과가 소득계층에 따 라 차별적으로 나타난다는 것에 주목할 필요가 있다. 무상복 지 정책의 혜택이 저소득층보다는 오히려 중산층이나 고소득 층으로 귀착될 가능성이 높다는 분석결과(Cho \& Yoo, 2013) 와 보육비 지원의 정책효과가 중산층에서 가장 크게 나타났다 는 분석결과(Hong, 2013)를 고려할 때, 무상보육정책 또한 소 득계층에 따라 차별적인 영향력을 미칠 가능성이 있다. 따라 서, 무상보육정책의 실질적인 소득재분배 효과를 평가하기 위 해서 무상보육정책 전후의 보육비 지출의 변화가 각 소득계층 에 따라 어떻게 차별적으로 나타나는지 살펴볼 필요성이 대두 된다.

가구소득은 아동 보육 및 교육에 투자 가능한 자원을 제공 한다는 점에서, 유아 보육비 - 사교육비와 밀접한 연관을 가지 는 것으로 연구되었다. 선행연구에서 가구소득은 어머니의 연 령, 어머니의 최종학력, 어머니의 취업여부, 자녀수와 함께 보 육비 지출에 영향을 미치는 주요변수로 다루어졌으며, 소득계 층이 높을수록 보육 및 교육비 지출이 높으며, 보육·교육비 지출에서 계층 간 차이가 큰 것으로 분석되었다(Baek \& Cho 2005; S. L. Lee, 2011). 또한 보육비 지원 정책의 효과가 가구의 소득수준에 따라 차별적으로 나타날 수 있는 것으로 밝혀졌 다. 가구의 소득계층에 따른 정부의 보육료 지원의 영향 차이 를 분석한 연구에서는 정부의 보육료지원이 2011년 영유아가 구 소득하위 70\%, 2012년 0-2세, 5세의 전 계층 지원으로 확대 되면서 소득집단 간 보육비 격차가 어느 정도 완화되었으나, 가구소득 대비 보육비 감소폭이 저소득가구보다 일반가구에 서 더 큰 것으로 나타났다(K. I. Kim, 2014).

가구소득은 아동 연령, 어머니 취업여부, 아동 출생순위, 자 녀수, 어머니 학력과 함께 사교육비에도 영향을 미치는 요인 으로 밝혀졌다(Kwon, 2011; Suh \& Yang, 2013). 미취학 아동
이 있는 가구의 경우 소득수준이 높을수록 사교육이용 가능성 이 높으며, 사교육비 수준도 높은 것으로 나타났다(J. K. Kim, 2004). 또한 선행연구에 따르면 소득계층에 따라 사교육비 격 차가 클 뿐만 아니라, 사교육비 지출 부담이 가구의 소득수준 에 따라 다르게 인지되는 것으로 나타났다. 교육 및 보육비 감 소폭은 대도시지역과 고소득계층, 새롭게 지원 대상에 포함된 가구에서 더 높았지만, 가계경제 도움 정도는 저소득 계층과 중소도시, 읍면 지역, 2011년 교육·보육비 지원 대상 가구가 더 높게 체감하는 것으로 보고되었다(Y. J. Lee et al., 2013). K. S. Lee와 Kim (2010)은 6세 이하의 유아 가구의 소득수준에 따라 생활비 중 사교육비가 차지하는 비율에서 유의한 차이를 발견 하지 못했는데, 이를 낮은 소득의 가구라 할지라도 생활비 대 비 사교육비 지출수준이 낮지 않다는 사실을 보여주는 것으로 해석하였다. 이러한 결과들을 통해서 소득계층에 따라 사교육 비 지출액의 차이뿐만 아니라 소득 대비 부담의 차이도 있을 것으로 예상할 수 있다.

앞서 제시한 선행연구의 결과를 모두 종합하여 볼 때, 가구 소득분위를 기준으로 하는 보육비 지원 대상의 확대 과정에서 보육비 및 사교육비의 지출 및 가구소득 대비 보육비 및 사교 육비 지출 부담이 변화하고, 이 변화가 소득계층에 따라 차별 적으로 나타났을 가능성이 존재한다. 특히 무상보육정책 시행 전후로 가구소득이 보육비와 사교육비 지출에 미치는 영향 또 한 변화하였을 것으로 예상된다. 보육비 지원 정책의 대상 범 위가 2009년부터 2013년까지 소득 하위 50\%, 70\%부터 전 계 층에 이르기까지 단계적으로 확대된 배경(MOHW, 2013)과 가구의 소득계층별 보육비 및 사교육비 지출 변화를 연관 지 어 분석할 때, 이러한 예상이 실제 현상과 부합하는지를 실제 적이고 통시적으로 확인할 수 있을 것이다.

따라서 이 연구에서는 무상보육정책의 확대 과정에서 나타 난 유아 보육비 및 사교육비의 변화 경향성을 소득계층별로 살펴보고, 무상보육정책 시행 전과 후의 가구소득, 보육비, 사 교육비의 관계를 검증하고 비교분석하고자 하였다. 이 연구의 연구문제는 다음과 같다.

\section{연구문제 1}

보육비 지원대상 확대 과정에서 유아 보육비, 사교육비의 변 화 경향은 어떠한가?

\section{연구문제 2}

보육비 지원대상 확대 과정에서 가구소득구분에 따른 유아 보육비, 사교육비의 변화 경향은 어떠한가? 


\section{연구문제 3}

무상보육정책 시행 전후 가구소득이 보육비, 사교육비에 미 치는 영향은 어떠한가?

\section{연구방법}

\section{연구대상}

이 연구는 한국복지패널의 자료를 분석하였다. 한국복지패널 은 한국보건사회연구원의 차상위빈곤패널, 자활패널과 서울 대학교 사회복지연구소의 한국복지패널을 통합하여 구성된 패널로, 빈곤층 및 다양한 인구집단의 규모, 생활실태, 복지욕 구를 파악하여 정책 형성 및 평가에 기여하기 위하여 수립되 었다. 2006년 1차 년도에 7,072가구를 조사하였고, 2012년 7 차 년도에 표본규모를 유지하기 위하여 1,800 가구를 추가하 였으며, 현재 2015년 10차 7,048가구를 조사하였으며 현재 9 차 년도까지 자료를 공개하고 있다. 즉, 한국복지패널은 다양 한 소득계층과 폭넓은 기간을 포괄한 분석을 하고자 하는 이 연구의 목적에 부합하는 적절한 사회조사 자료라 할 수 있다.

이 연구는 한국복지패널에서 제공하는 2010년 5차 년도 (2009년 기준)부터 2014년 9차 년도(2013년 기준)까지의 자료 를 이용하였다. 이는 2009년 6월까지는 법정저소득층, 차상위 계층, 도시근로자가구 평균소득을 기준으로 보육비가 지원되 었던 것과 달리, 2009년 7월부터는 소득분위를 기준으로 보육 비 지원 정책의 점진적 확대가 이루어졌기 때문이다. 따라서 보육비 지원 소득분위 범위가 점차 확대되어 무상보육정책이 시행되기까지의 과정을 분석하기 위해서는, 2009년의 소득과 보육비.사교육비를 조사한 2010년 5차 년도 자료부터를 분석 대상으로 결정하는 것이 타당하다고 할 수 있다.

같은 학령기 이전 연령이더라도 영아 사교육은 보육의 성 격이 강하며 유아 사교육은 취학을 위한 준비학습의 성격이 강하다는 점(J. K. Kim, 2004)을 고려할 때, 영아와 유아의 보 육비 및 사교육비를 구분하여 살펴볼 필요성이 있다. 이 연구 에서는 영아기에 비해 취학 준비를 위한 사교육비 지출이 많 은 유아기(J. K. Kim, 2004)에 한정하여 연구를 수행하였다.

유아 1 인당 보육비 및 사교육비를 분석하기 위해 먼저 전 체 가구원 중에서 유아 가구원을 추출해냈다. 이를 위해 각 연 도별 가구용 자료에서 출생년도를 기준으로 3세, 4세, 5세에 해당하는 유아들을 선정하는 과정을 거쳤다. 5 차 년도 자료 (2009년 기준) 가구원 중에서 2003, 2004, 2005년생 유아를, 6
차 년도 자료(2010년 기준)에서 2004, 2005, 2006년생 유아를, 7차 년도 자료(2011년 기준)에서 2005, 2006, 2007년생 유아 를, 8차 년도 자료(2012년 기준)에서 2006, 2007, 2008년생 유 아를, 9차 년도 자료(2013년 기준)에서 $2007,2008,2009$ 년생 유아를 선정하였다. 그 결과 연도별로 연구대상으로 선정된 유아는 5차 년도(2009년 기준) 492명, 6차 년도(2010년 기준) 453명, 7차 년도(2011년 기준) 528명, 8차 년도(2012년 기준) 513명, 9차 년도(2013년 기준) 461명이었다. 이렇게 선정된 유 아 가구원의 개인별 가구소득, 보육비 및 교육비 자료를 생성 하여 분석에 활용하였다. 연구대상으로 선정된 유아들의 일반 적 특성을 살펴보면 Table 1과 같다.

유아의 거주 지역은 시에 거주하는 경우가 $40 \%$ 내외로 가 장 높은 비중을 차지하고 광역시 $30 \%$ 내외, 서울 $13 \%$ 가량으 로 그 다음을 이었고 도농복합군은 $2 \%$ 내외로 가장 적었다. Statistics Korea (2015b)의 중위소득 기준으로 구분한 소득계층 별 가구분포를 살펴보면 중위소득의 $60 \%$ 이하인 저소득 가 구가 9.7-7.6\%, 중위소득의 60-150\%인 중소득 가구가 66.8$71.0 \%$, 중위소득의 $150 \%$ 이상인 고소득 가구가 $19.3-25.6 \%$ 정도를 차지하는 것으로 나타났다. 유아 연령은 3세, 4 세, 5 세 가 모든 년도의 자료에서 $29.1-36.7 \%$ 사이로 고른 비중을 차 지하고 있는 것으로 분석되었다.

\section{연구도구}

유아의 보육비 및 사교육비를 측정하기 위해, 성인 가구원이 응답한 각 아동의 한 달 평균 사교육비 및 보육비를 측정한 2 개의 문항을 사용하였다. 구체적인 문항 내용은 "귀 댁에서 각 각의 아동(자녀)에게 든 사교육비는 한 달 평균 얼마입니까? 교재비, 재료비, 간식비 등 부대비용까지 포함하여 다음의 응 답지를 아동별로 기재해 주시오.", "귀 댁에서 각각의 아동(자 녀)에게 든 보육비는 한 달 평균 얼마입니까? 교재비, 재료비, 간식비 등 부대비용까지 포함하여 다음의 응답지를 아동별로 기재해 주시오.”이다. 한국복지패널에서 제공하는 원자료는 가구를 기준으로 복수의 자녀의 보육비 및 사교육비가 병렬적 으로 포함되어 있는 형태로 구성되어 있다. 이를 개별 유아가 분석단위인 이 연구에 적합한 형태로 활용할 수 있도록, 개별 유아를 기준으로 재정렬하여 유아 개인별로 소요된 보육비 및 사교육비를 파악할 수 있는 형태로 자료를 가공하였다.

가구소득을 측정하기 위해 가구의 가처분소득을 이용하였 다. 한국복지패널은 가처분소득으로 경상소득에서 비소비 지 출(사회보장 부담금, 소득세)를 제외한 값을 제공한다. 가처분 
Table 1

General Characteristics of the Participants

$f(\%)$

\begin{tabular}{llrrrrr}
\hline \multirow{2}{*}{ Variable } & Residence & $\begin{array}{c}\text { Sth year } \\
(2009)\end{array}$ & $\begin{array}{c}\text { 6th year } \\
(2010)\end{array}$ & $\begin{array}{c}\text { 7th year } \\
(2011)\end{array}$ & $\begin{array}{r}\text { 8th year } \\
(2012)\end{array}$ & $\begin{array}{c}\text { 9th year } \\
(2013)\end{array}$ \\
\hline Province & Seoul & $73(14.8)$ & $66(14.6)$ & $77(14.6)$ & $70(13.6)$ & $56(12.1)$ \\
& Metropolitan city & $152(30.9)$ & $135(29.8)$ & $161(30.5)$ & $159(31.0)$ & $134(29.1)$ \\
& City & $194(39.4)$ & $190(41.9)$ & $219(41.5)$ & $227(44.2)$ & $222(48.2)$ \\
& County & $66(13.4)$ & $54(11.9)$ & $58(11.0)$ & $46(9.0)$ & $38(8.2)$ \\
& Urban-rural consolidated city & $7(1.4)$ & $8(1.8)$ & $13(2.5)$ & $11(2.1)$ & $11(2.4)$ \\
& Total & $492(100)$ & $453(100)$ & $528(100)$ & $513(100)$ & $461(100)$ \\
Income group & Lower income & $44(8.9)$ & $28(6.2)$ & $51(9.7)$ & $47(9.2)$ & $35(7.6)$ \\
& Middle income & $345(70.1)$ & $321(70.9)$ & $375(71.0)$ & $349(68.0)$ & $308(66.8)$ \\
& Higher income & $103(20.9)$ & $104(23)$ & $102(19.3)$ & $117(22.8)$ & $118(25.6)$ \\
& Total & $492(100)$ & $453(100)$ & $528(100)$ & $513(100)$ & $461(100)$ \\
& Age & $157(31.9)$ & $159(35.1)$ & $197(33.9)$ & $168(32.7)$ & $134(29.1)$ \\
& 3 years & $158(32.1)$ & $142(31.3)$ & $191(36.2)$ & $164(32.0)$ & $169(36.7)$ \\
& 4 years & $177(36)$ & $152(33.6)$ & $158(29.9)$ & $181(35.3)$ & $158(34.3)$ \\
& 5years & $492(100)$ & $453(100)$ & $528(100)$ & $513(100)$ & $461(100)$ \\
\hline
\end{tabular}

소득은 개인이 소비나 저축에 대해 의사결정을 하는 기본적 인 바탕이 되기 때문에 유아자녀 보육비 및 사교육비 지출과 의 관련성을 살펴보는 데에 적합한 소득구분이라고 할 수 있 다. 가처분소득을 측정할 때, 가구별 가구원수의 차이를 고려 하여 가구의 경제적 욕구를 비교하기 위해 가구 균등화 지수 (equivalence scale)를 적용한 균등화가처분소득을 사용하였다 $(\mathrm{Ku}, \mathrm{Son}, \& \mathrm{Ahn}, 2010)$. 균등화가처분소득은 가구총소득을 가구 균등화 지수로 나누어 계산하였으며, 가구 균등화 지수 로는 $\mathrm{OECD}$ 를 비롯한 국제비교에서 널리 사용되는 가구원수 의 제곱근을 사용하였다. 계산과정은 다음과 같다.

$$
\text { 균등화된 소득 }=\frac{\text { 소득 }}{\sqrt{\text { 가구원수 }}}
$$

연구문제 1 과 연구문제 2 에서는 실제 수치를 제시하는 데 에 목표가 있기 때문에 균등화가처분소득을 사용하여 제시하 였다. 가처분소득의 경우 일반적인 소득의 분포와 마찬가지로 정적 편포를 보이는 경향성이 나타난 점을 보완하여, 연구문 제 3에서는 균등화가처분소득에 자연로그를 취하여 회귀분석 에 적합한 형태로 변수를 가공하여 분석하였다.

소득계층 구분은 한국복지패널 기준과 학술적으로 통용되 는 기준을 결합하여 활용하였다. 이 연구에서는 한국복지패널 이 제시한 것과 같이 균등화가처분소득을 기준으로 중위소득
의 $60 \%$ 이하인 가구를 저소득 가구로 분류하였다. 저소득 가 구 이외의 소득계층은 $\mathrm{OECD}$ 기준에 따라서 중위소득의 60 $150 \%$ 사이인 가구를 중소득 가구로, 중위소득의 $150 \%$ 이상 인 가구를 고소득 가구로 구분하였다(Statistics Korea, 2015b).

\section{자료분석}

데이터는 SPSS Statistics 22.0 (IBM Co., Armonk, NY)를 이용하 여 분석하였다. 유아 보육비 및 사교육비의 전반적인 경향을 파악하기 위해 기술통계 분석을 실시하였다. 5차 년도(2009 년 기준)부터 9차 년도(2013년 기준)까지 각 연도의 유아 보육 비 및 사교육비, 균등화가처분소득 대비 보육비 및 사교육비 의 평균과 표준편차를 계산하였다. 가구소득, 보육비, 사교육 비 간의 상관관계를 검증하기 위하여 상관관계분석을 실시하 였으며, 통제변수들을 통제하였을 때의 가구소득이 보육비와 사교육비에 미치는 영향을 검증하기 위하여 위계적 회귀분석 을 실시하였다. 구체적으로는 2013년 무상보육 전면시행 시 점을 전후로 5차 년도(2010년)과 9차 년도(2014년) 두 개 년도 의 자료를 이용하여 가구소득, 보육비, 사교육비 간의 Pearson 상관계수를 도출하고, 보육비와 사교육비에 대한 회귀모형 을 산출한 후 Durbin-Watson 통계량과 분산팽창계수(Variation Inflation Factor [VIF])를 확인하였다. 


\section{연구결과}

\section{보육비, 사교육비 변화 경향}

5차 년도(2009년 기준)부터 9차 년도(2013년 기준)까지의 3 세-5세 유아의 일인당 보육비 및 사교육비의 평균값 변화 경 향을 나타낸 그래프는 Figure 1과 같다. 먼저 보육비는 2010년 에 소폭 상승했다가 2013년에는 다시 하락하는 추세를 보인 다. 유아 1 인당 보육비 지출은 2009년 평균 약 122,200 원에서 2013년 평균 약 105,800 원으로 하락한 것으로 나타났다. 즉, 2013년 3월 무상보육정책 실시로 인한 보육비 지원이 이루어 지면서 유아 1 인당 보육비가 감소하였다고 할 수 있다. 사교육 비의 경우, 2009-2013년 변화 경향성이 보육비와 상하 대칭적 인 그래프 모양을 보여주고 있다. 증감 경향을 보면, 보육비와 반대로 2011년까지 소폭 하락했다가, 2013년까지 다시 소폭 상승하는 경향이 나타났다.

다음으로 보육비와 사교육비의 실제 가구부담 정도를 파악 하는 위하여 가구 가처분소득 대비 유아 보육비, 사교육비 변 화 경향을 산출하였다. Figure 2 를 보면 보육비와 사교육비 지 출만 분석하였을 때와 달리, 균등화가처분소득 대비 유아 보 육비, 사교육비는 모두 2009-2013년 사이 전반적으로 감소 하는 경향을 나타내었다. 특히 사교육비의 경우 사교육비 지 출액 평균 자체는 2009년과 2013년에 큰 차이를 보이지 않았 지만, 균등화가처분소득 대비 사교육비 지출은 2009년보다 2013년에 그 비율이 하락한 것을 알 수 있다. 균등화가처분 소득 대비 보육비도 마찬가지로 2010년에 조금 상승했다가 2010년 이후 꾸준한 하락세를 나타냈으며, 그 하락폭은 무상 보육정책을 실시한 2013년에 가장 크게 나타났다.

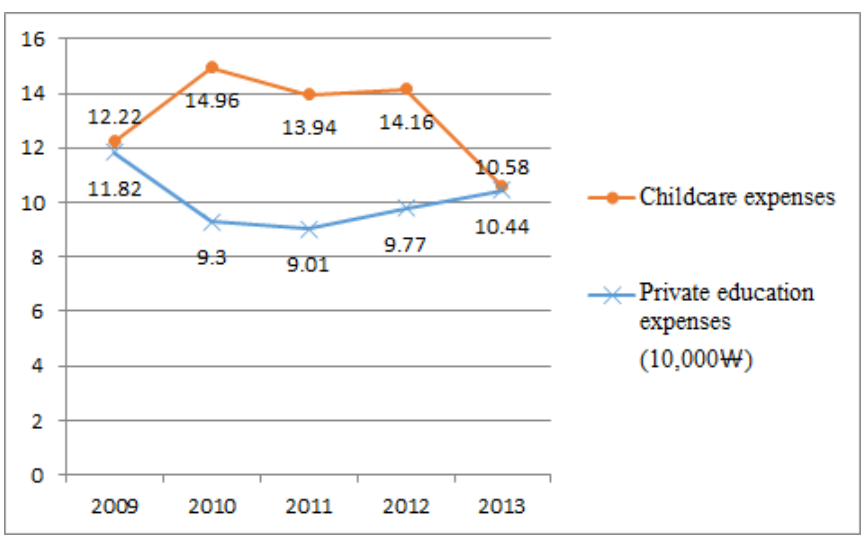

Figure 1. The pattern of changes in childcare expenses and private education expenses.

\section{가구소득구분에 따른 보육비, 사교육비 변화 경향}

가구소득구분에 따라 유아 보육비와 사교육비의 변화 경향성 을 분석한 결과는 Figure 3 및 Figure 4와 같다. 전체적인 경향 은 보육비와 사교육비 모두 2009-2012년 사이에 고소득가구 와 저·중소득가구 간의 격차가 크게 나타났으며, 2013년 무상 보육정책 시행으로 인해 고소득가구의 보육비는 중소득가구 수준으로 낮아졌지만, 사교육비의 경우 고소득과 저·중소득 가구 간 격차가 더 커진 것으로 나타났다.

먼저 가구소득구분별 보육비 분석결과를 살펴보면(Figure 3), 중소득가구 유아의 보육비 평균은 2009년부터 2013년 사 이에 일정한 수준으로 유지되었고, 저소득가구 유아의 보육비 평균값은 2009년부터 2010년까지는 소폭 상승하다가 2011년 부터 2013년까지는 다시 소폭 하락하는 경향을 보였다. 고소 득과 중소득은 매우 큰 격차를 나타내다가, 2013년 무상보육 정책 실시 이후 고소득 가구와 중소득 가구의 유아 1 인당 보육 비 지출 평균이 수렴하는 양상을 나타내었다. 종합하여 볼 때, 2011년 이후로 저소득층 보육비 지원 정책이 확대 시행되면 서 저소득 가구의 보육비는 소폭 하락하고, 2013년에는 정부 의 전 계층 보육비 지원으로 인해 고소득 보육비 지출이 대폭 하락하여, 고소득, 중소득, 저소득의 보육비 지출 차이가 감소 하는 경향성을 보였다.

가구소득구분에 따른 사교육비 변화 경향의 경우(Figure 4), 고소득과 저소득 가구의 사교육비 변화는 보육비 지출 변화 그래프와 반대되는 경향성을 나타냈다. 먼저 저소득가구의 유 아 사교육비 평균값은 2011년까지는 하락하다가, 저소득 가구

대상 보육비 지원이 실시되기 시작한 2011년부터 점진적 으로 상승하는 경향성을 나타냈다. 중소득가구의 유아 사교

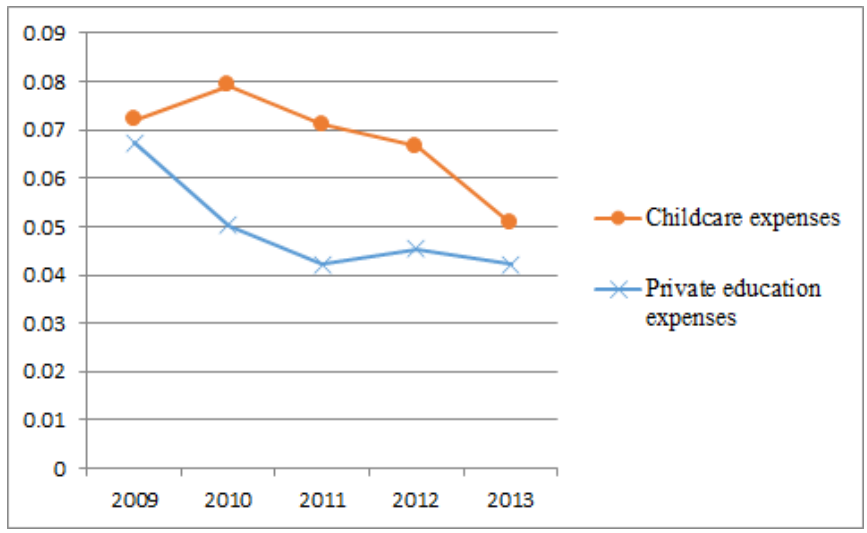

Figure 2. The pattern of changes in childcare expenses and private education expenses to household disposable income. 


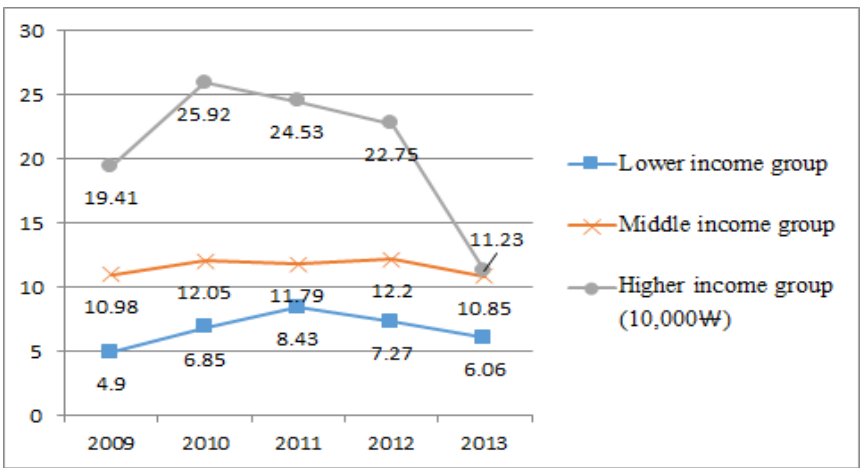

Figure 3. The pattern of changes in childcare expenses according to income groups.

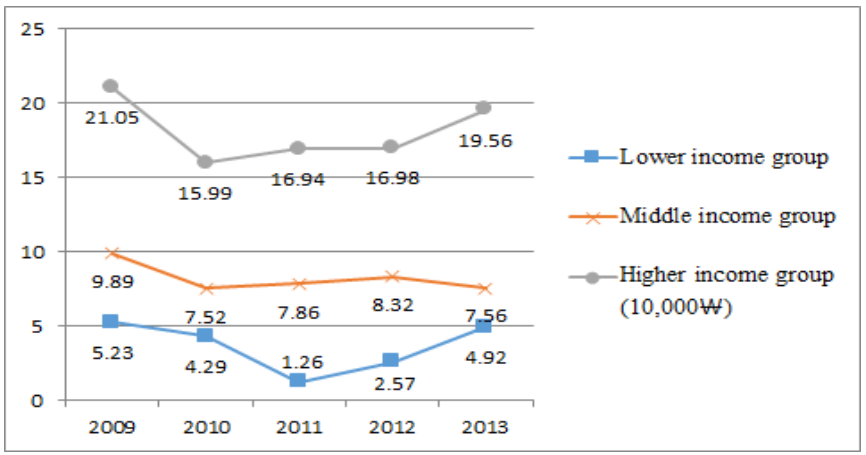

Figure 4. The pattern of changes in private education expenses according to income groups.

육비 평균값은 보육비보다 3 만원에서 5 만 원 정도의 낮은 수 준으로 일정하게 유지되었다. 고소득가구의 유아 사교육비는 2009년 중소득과 저소득가구보다 훨씬 높은 수준을 나타냈는 데 2010년부터 2012년까지는 소폭 하락하였다가 2013년에 다 시 2009년 수준으로 회복되는 양상을 보였다. 결과적으로 보 육비와 달리 사교육비 지출은 2013년 무상보육정책 시행 이 후 고소득가구와 중소득가구 간의 격차가 더 커진 것으로 나 타났다. 2012년에 비하여 2013년 사교육비 평균 상승폭은 고 소득과 저소득층이 유사하게 나타나, 고소득 가구와 저소득 가구의 사교육비 지출 금액 격차는 무상보육정책과 관계없이 동일한 수준을 유지하였다.

다음으로 가구소득구분에 따른 소득 대비 유아 1 인당 보육 비, 사교육비 부담의 변화를 알아보기 위해 균등화가처분소득 대비 보육비와 사교육비의 변화를 알아본 결과는 Figure 5 및 Figure 6과 같다. 전반적으로 가장 두드러지게 나타나는 경향 성을 살펴보면, 저소득가구의 균등화가처분소득 대비 보육비, 사교육비는 중·고소득 가구보다 높은 수준을 유지하다가, 저 소득층 대상 보육비 지원 정책이 실시된 2011년부터는 중·고
소득 가구와 유사한 수준으로 낮아졌다.

균등화가처분소득 대비 보육비를 가구소득구분에 따라 살 펴보면(Figure 5), 중소득과 고소득가구는 2009-2013년 사이에 동일한 수준을 유지하는 것으로 나타났다. 반면에 저소득가구 는 2010년에 균등화가처분소득 대비 보육비가 상승하였다가 0-5세 영유아 가구 소득하위 70\% 보육비 지원이 실시된 2011 년에는 중소득과 고소득을 약간 상회하는 수준을 유지하며 점 진적으로 소폭 하락하는 경향을 보여주었다. 그럼에도 불구하 고 2009-2013년 동안 균등화가처분소득 대비 보육비 수준이 저소득 가구에서 가장 높은 것으로 나타나 저소득 가구의 보 육비 부담이 여전히 가장 큰 것으로 분석되었다.

Figure 6을 보면, 균등화가처분소득 대비 사교육비는 중소 득, 고소득 가구에서 전 기간 동안 동일한 수준을 유지하였지 만 저소득가구의 경우 매우 큰 폭의 변동을 보이는 것으로 나 타났다. 저소득 가구의 사교육비 부담은 소득 하위 $70 \%$ 인 가 구를 대상으로 0-5세 영유아 보육비 전액지원이 실시된 2011

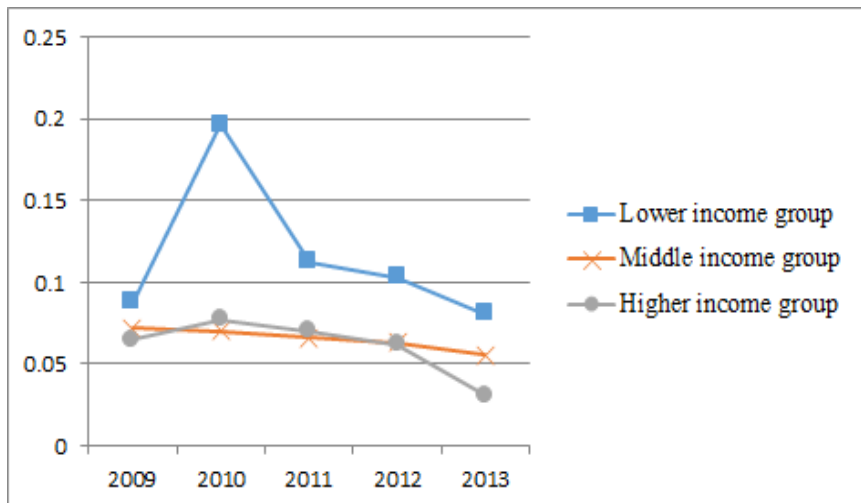

Figure 5. The pattern of changes in childcare expenses to household disposable income according to income groups.

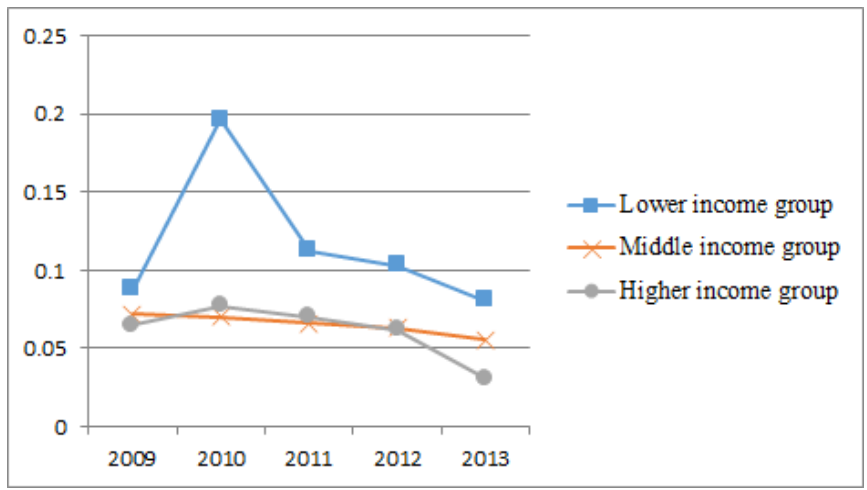

Figure 6. The pattern of changes in private education expenses to household disposable income according to income groups. 
년에 가장 낮은 수준을 나타내었으나, 2012년 이후로는 다시 상승하여 2013년에는 중소득과 고소득보다 높거나 유사한 수 준을 나타낸 것으로 파악되었다.

\section{무상보육정책 시행 전후 가구소득, 보육비, 사 교육비의 관계}

\author{
무상보육정책 시행 전 가구소득, 보육비, 사교 \\ 육비의 관계
}

무상보육정책 시행 전후로 가구소득, 보육비, 사교육 간의 관 계에 어떠한 차이가 있는지 검증하기 위하여, 2009년(5차 년 도)과 2013년(9차 년도) 두 시점을 선정하여 균등화가처분소 득, 보육비, 사교육비 간의 상관관계를 분석하였다. 또한 선행 연구에서 보육비와 사교육비에 영향을 미치는 것으로 나타난 통제변수들을 통제한 상태에서, 무상보육정책 시행 전후의 보 육비와 사교육비 지출에 대한 가구소득의 영향력 차이를 비교 하기 위해, 위계적 회귀분석을 실시하였다. 균등화가처분소득 은 양적편포를 보이는 경향이 나타나 자연로그(natural log)를 취하여 분석에 활용하였다.

먼저 무상보육정책 실시 전 5차 년도(2009년 기준) 자료에 서 균등화가처분소득, 보육비, 사교육비 간의 상관관계를 알 아보기 위하여 상관계수를 도출하였다. Table 2 를 보면, 균등 화가처분소득은 보육비와 양의 상관관계를 가지고 있으며 $(r=$ $.314, p<.001)$, 사교육비와는 양의 상관관계를 가지고 있었다 $(r=.326, p<.001)$. 보육비와 사교육비는 음의 상관관계를 나 타냈다 $(r=-.199, p<.001)$. 이는 소득이 높아질수록 보육비 및 사교육비 지출도 늘어난다는 것을 보여준다. 보육비에 비하여 사교육비는 상대적으로 균등화가처분소득과 높은 상관관계 를 나타냈다.

회귀분석을 실시하기에 앞서, 무상보육정책 실시 전 시점 의 보육비와 사교육비에 대한 회귀분석 모형이 중다회귀분석
의 기본가정을 충족하는지 살펴보았다. 오차항의 독립성을 확 인하기 위해 Durbin-Watson 통계량을 살펴본 결과, 보육비와 사교육비 회귀모형의 통계량에 2에 근접하여 오차항이 독립 적인 것으로 나타났다 $($ 보육비 $=2.000$, 사교육비 $=1.980)$. 독 립변수들 간의 다중공선성을 확인한 결과, 독립변수들 간의 상관계수가 모두 .8 이하로 나타나고 VIF가 10 미만인 것으로 나타나 다중공선성의 문제가 없는 것으로 판단하였다.

먼저, 무상보육정책 실시 이전 시점의 보육비에 영향을 미 치는 요인들을 알아보기 위하여 2009년(5차 년도) 자료를 이 용하여 위계적 회귀분석을 실시하였으며 그 결과는 Table 3에 제시되었다. 1 단계는 통제변수로 부모의 교육수준, 모의 취업 여부, 가구의 자녀수, 유아의 출생순위 및 연령, 거주지역을 투 입하였으며, 2 단계는 균등화가처분 소득을 추가하였다.

통제변수를 투입한 1 단계의 경우 독립변수가 보육비의 $9.8 \%$ 를 설명하는 것으로 나타났으며, 이 회귀모형은 통계적 으로 유의했다 $(F=4.131, p<.001)$. 가구의 자녀수가 증가할 수록 유아 1 인당 보육비는 감소하는 것으로 나타났으며 $(\beta=$ -.124, $p<.05)$, 유아의 연령이 증가할수록 보육비가 증가하는 것으로 나타났다 $(\beta=.131, p<.01)$.

균등화가처분소득을 추가한 2단계의 경우 독립변수가 보 육비의 $13.6 \%$ 를 설명하는 것으로 나타났으며, 이 회귀모형은 통계적으로 유의했다 $(F=5.406, p<.001)$. 또한 균등화가처분 소득의 추가로 인한 모형의 $R^{2}$ 증가량은 .038 로 나타났으며 이 는 통계적으로 유의했다 $(F=16.476, p<.001) .2$ 단계에서는 통 제변수 중에서는 자녀의 연령만 통계적으로 유의하였으며, 자 녀의 연령이 증가할수록 보육비도 증가하는 것으로 나타났다 $(\beta=.110, p<.05)$. 균등화가처분소득이 높을수록 보육비 지출 이 증가하며 $(\beta=.220, p<.001)$, 투입된 독립변수들의 표준화 된 $\beta$ 값들과 비교해볼 때 독립변수 중에서 균등화가처분소득 이 보육비에 가장 큰 영향을 미친 것으로 나타났다.

다음으로는 무상보육정책실시 이전 시점의 사교육비에 영 향을 미치는 요인들을 알아보기 위하여 2009년(5차 년도)자

Table 2

Correlations of Analyzed Variables of 5th Year (2009) Data

\begin{tabular}{|c|c|c|c|}
\hline & Private education expenses & Childcare expenses & Ln equalized disposable income \\
\hline Private education expenses & - & & \\
\hline Childcare expenses & $-.199^{* * *}$ & - & \\
\hline
\end{tabular}

Note. Ln is an abbreviation of natural $\log$.

${ }^{* *} p<.01 .{ }^{* * *} p<.001$. 
Table 3

Hierarchial Multiple Regression Analysis: The Effects of Household Income on Preschool Childcare Expenses of 5th Year (2009) Data

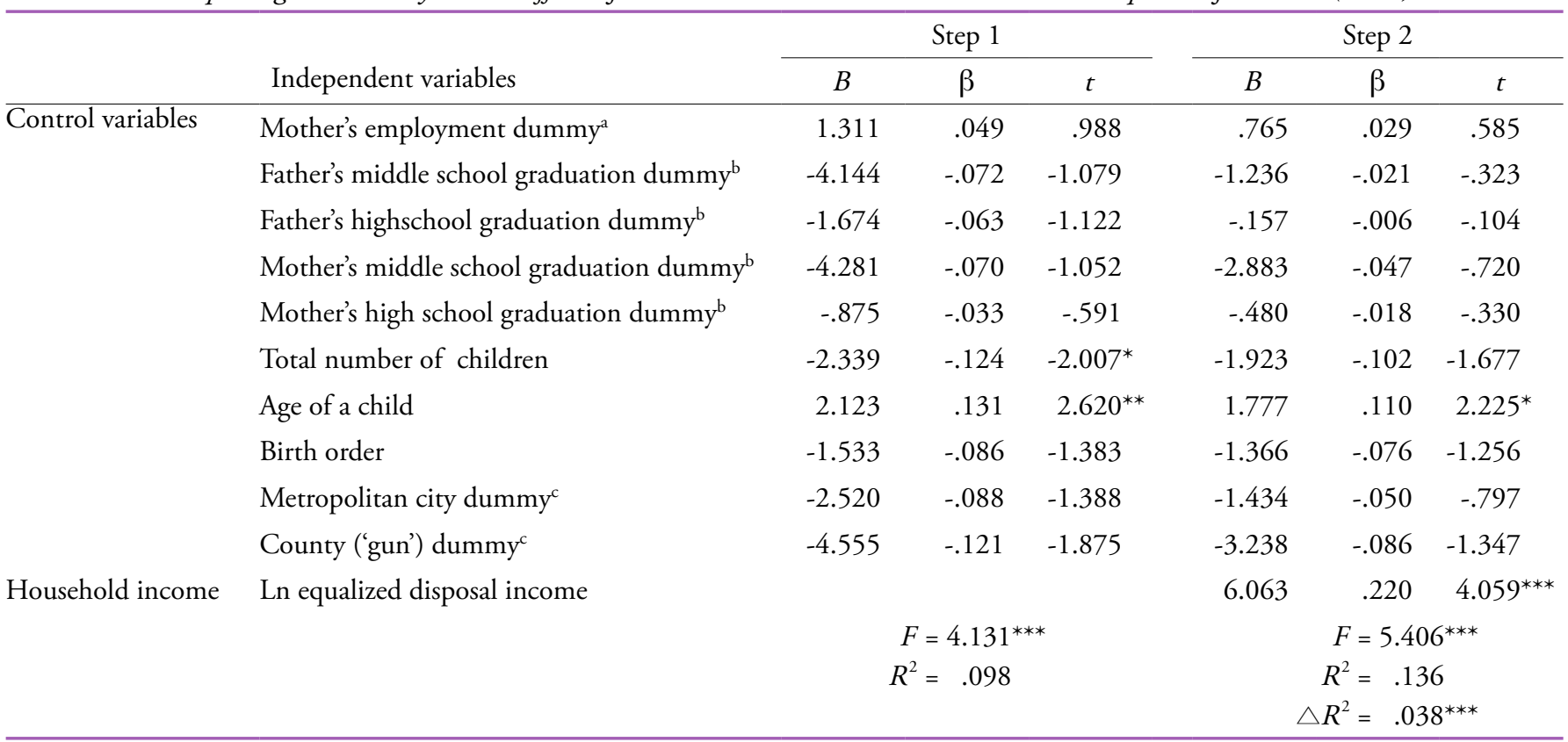

Note. $\mathrm{Ln}$ is an abbreviation of natural $\log$.

${ }^{\mathrm{a}} 1=$ employed, $0=$ unemployed; $^{\mathrm{b}} 1=$ college graduate, $0=$ middle $/$ high school graduate; ${ }^{\mathrm{c}} 1=$ Seoul, $0=$ metropolitan city $/$ county

${ }^{*} p<.05 .{ }^{* *} p<.01 .{ }^{* * *} p<.001$.

료를 이용하여 위계적 회귀분석을 실시하였으며 그 결과는 Table 4에 제시되었다. 1단계는 부모의 교육수준, 모의 취업여 부, 가구의 자녀수, 유아의 출생순위 및 연령, 거주지역이 포 함되었으며, 2 단계는 균등화가처분 소득을 추가하여 분석하 였다.

통제변수를 포함시킨 1 단계의 경우 독립변수가 사교육비 의 $12.7 \%$ 를 설명하는 것으로 나타났으며, 통계적으로 이 회 귀모형은 유의했다 $(F=5.537, p<.001)$. 아버지의 최종학력이 중학교 졸업 이하보다 대학 졸업인 경우인 경우 $(\beta=-.152, p<$ $.05)$, 가구의 총 자녀수가 감소할수록 $(\beta=-.143, p<.05)$, 유아 의 연령이 감소할수록 $(\beta=-.248, p<.001)$ 사교육비가 증가하 는 것으로 나타났다. 시에 거주하는 경우보다 서울에 거주하 는 경우 $(\beta=-.166, p<.01)$ 와 군에 거주하는 경우보다 서울에 거주하는 경우 $(\beta=-.144, p<.05)$ 사교육비가 증가하는 것으로 나타났다.

균등화가처분소득을 투입한 2단계의 경우 독립변수가 사 교육비의 $21 \%$ 를 설명하는 것으로 나타났으며, 통계적으로 이 회귀모형은 유의했다 $(F=9.173, p<.001)$. 균등화가처분소득 으로 인한 $R^{2}$ 증가량은 .083 으로 이는 통계적으로 유의한 증가 량 이었다 $(F=42.274, p<.001)$. 통제변수의 경우 1 단계에서
유의한 변수였던 아버지의 최종학력, 가구의 자녀수는 2 단계 에서는 유의하지 않은 것으로 분석되었다. 유아의 연령은 1 단 계와 마찬가지로, 연령이 감소할수록 사교육비가 증가하는 것 으로 나타났다 $(\beta=-.279, p<.001)$. 균등화가처분소득이 증가 할수록 사교육비도 증가하는 것으로 나타났으며 $(\beta=.327, p<$ $.001)$, 균등화가처분소득의 표준화된 $\beta$ 값을 다른 변수들과 비 교해볼 때 가장 큰 것으로 나타나, 독립변수 중에서 균등화가 처분소득이 사교육비에 미치는 영향이 가장 큰 것으로 나타났 다. 또한 보육비에 대한 균등화가처분소득의 표준화된 $\beta$ 값과 비교해볼 때, 사교육비에 대한 균등화가처분소득의 표준화된 $\beta$ 값이 다소 더 큰 것으로 분석되었다. 이는 가계소득이 보육 비보다 사교육비에 미치는 영향이 큰 것으로 해석된다.

\section{무상보육정책 시행 후 가구소득, 보육비, 사교 육비의 관계}

2013년 무상보육정책이 실시된 후 가구소득, 보육비, 사교육 비의 관계에 변화가 생겼는지 확인하기 위하여, 위와 동일하 게 9차 년도(2013년 기준) 데이터에 대해 상관관계분석, 위계 적 회귀분석을 실시하고 그 결과를 5차 년도(2009년 기준) 분 
Table 4

Hierarchial Multiple Regression Analysis: The Effects of Household Income on Preschool Private Education Expenses of 5th Year (2009) Data

\begin{tabular}{|c|c|c|c|c|c|c|c|}
\hline & \multirow[b]{2}{*}{ Independent variables ${ }^{a}$} & \multicolumn{3}{|c|}{ Step 1} & \multicolumn{3}{|c|}{ Step 2} \\
\hline & & $B$ & $\beta$ & $t$ & $B$ & $\beta$ & $t$ \\
\hline \multirow[t]{7}{*}{ Control variables } & Mother's employment dummy ${ }^{\mathrm{b}}$ & -1.908 & -.061 & -1.242 & -2.882 & -.092 & -1.959 \\
\hline & Father's highschool graduation dummy ${ }^{\mathrm{b}}$ & -2.169 & -.070 & -1.259 & .462 & .015 & .273 \\
\hline & Mother's middle school graduation dummy & -1.379 & -.019 & -.293 & 1.083 & .015 & .240 \\
\hline & Total number of children & -3.168 & -.143 & $-2.352^{*}$ & -2.432 & -.109 & -1.888 \\
\hline & Age of a child & -4.744 & -.248 & $-5.045^{* * *}$ & -5.340 & -.279 & $-5.930^{* * *}$ \\
\hline & Birth order & .686 & .032 & .534 & .985 & .047 & .804 \\
\hline & Metropolitan city dummy ${ }^{c}$ & -5.602 & -.166 & $-2.663^{* *}$ & -3.695 & -.109 & -1.824 \\
\hline Household income & & \multicolumn{3}{|c|}{$R^{2}=.127$} & \multicolumn{3}{|c|}{$\begin{aligned} R^{2} & =.210 \\
\triangle R^{2} & =.083^{* * *}\end{aligned}$} \\
\hline
\end{tabular}

Note. $\mathrm{Ln}$ is an abbreviation of natural $\log$.

${ }^{\mathrm{a}} 1=$ employed, $0=$ unemployed; $^{\mathrm{b}} 1=$ college graduate, $0=$ middle $/$ high school graduate; ${ }^{\mathrm{c}} 1=$ Seoul, $0=$ metropolitan city $/$ county ${ }^{*} p<.05 .{ }^{* *} p<.01 .{ }^{* * *} p<.001$.

석결과와 비교하였다.

무상보육정책 시행 후 시점인 2013년의 균등화가처분소 득, 보육비, 사교육비의 상관관계를 살펴본 결과는 Table 5 와 같다. 2009년의 분석결과와 마찬가지로 균등화가처분소득은 보육비 $(r=.147, p<.01)$, 사교육비 $(r=.359, p<.001)$ 와 양의 상관관계를 나타냈다. 보육비와 사교육비 사이의 부적 관계 $(r$ $=-.123, p<.01)$ 도 2009년 분석결과와 동일하게 나타났다. 그 러나 2009년에는 소득과 보육비 $(r=.314, p<.001)$, 소득과 사 교육비 $(r=.326, p<.001)$ 간의 상관계수가 거의 유사하게 나타 났던 것에 비하여, 2013년에는 균등화가처분소득과 보육비의 상관계수가 급격하게 낮아진 것으로 나타났다. 반대로 균등화 가처분소득과 사교육비의 상관계수는 2012년에 비해 2013년 에 다소 상승한 것으로 나타났다. 이는 무상보육정책 시행에 따라 소득수준에 관계없이 보육비 지원 혜택을 받게 되어 소 득수준과 보육비 간의 관계가 약화되었지만, 사교육비는 오히 려 소득수준과의 관계가 강화된 것을 보여준다.

무상보육정책 실시 후 시점의 보육비와 사교육비에 대한 회귀분석 모형이 중다회귀분석의 기본가정을 충족하는지 살 펴보았다. 오차항의 독립성을 확인하기 위해 Durbin-Watson 통계량을 살펴본 결과, 보육비와 사교육비 회귀모형의 통계량
에 2에 근접하여 오차항이 독립적인 것으로 나타났다(보육비 $=1.880$, 사교육비 $=1.873$ ) 독립변수들 간의 다중공선성을 확 인한 결과, 독립변수들 간의 상관계수가 모두 8 이하로 나타 나고 VIF가 10 미만인 것으로 나타나 다중공선성의 문제가 없 는 것으로 판단하였다.

무상보육정책 실시 이후 시점의 보육비에 영향을 미치는 요인들을 알아보기 위하여 2013년(9차 년도)자료를 이용하여 위계적 회귀분석을 실시하였다(Table 6). 1단계에는 통제변수 로 부모의 교육수준, 모의 취업여부, 가구의 자녀수, 유아의 출 생순위 및 연령, 거주지역이 포함되었고, 2 단계는 균등화가처 분소득을 추가하였다.

통제변수를 투입한 1 단계의 경우, 독립변수가 보육비의 $10.8 \%$ 를 설명하는 것으로 나타났으며, 통계적으로 이 회귀모 형은 유의했다 $(F=4.589, p<.001)$. 통제변수 중에서 가구의 총 자녀수가 적을수록 유아 1 인당 보육비는 증가하는 것으로 나타났으며 $(\beta=-.152, p<.01)$, 거주지역이 서울인 경우보다 시 $(\beta=-.318, p<.001)$ 또는 군 $(\beta=-.276, p<.001)$ 지역일 경우 보육비가 감소하는 것으로 나타났다.

2단계에서 독립변수로 투입된 균등화가처분소득은 보육비 의 $9.1 \%$ 를 설명하는 것으로 나타났으며, 이 회귀모형은 통계 
Table 5

Correlations of Analyzed Variables of 9th Year (2013) Data

\begin{tabular}{|c|c|c|c|}
\hline & Private education expenses & Childcare expenses & Ln Equalized disposable income \\
\hline Private education expenses & - & & \\
\hline Childcare expenses & $-.123^{* *}$ & - & \\
\hline
\end{tabular}

Note. $\mathrm{Ln}$ is an abbreviation of natural $\log$.

${ }^{* *} p<.01 .{ }^{* * *} p<.001$.

적으로 유의했다 $(F=4.531, p<.001)$. 균등화가처분소득으로 인한 $R^{2}$ 증가량은 .008 로 이는 통계적으로 유의하지 않았다. 새롭게 추가된 균등화가처분소득이 보육비에 미치는 영향도 통계적으로 유의하지 않는 것으로 나타났다 $(\beta=.101, p>.05)$. 이는 무상보육정책 실시로 인하여 가계소득과 상관없이 보육 비 지원을 받게 되면서, 가계소득과 보육비 지출의 연관관계 가 약화된 것으로 해석할 수 있다.

무상보육정책 실시 후 사교육비에 영향을 미치는 요인들을 알아보기 위하여 2013년(9차 년도)자료를 이용하여 위계적 회 귀분석을 실시하였으며 그 결과는 Table 7에 제시하였다. 1단 계는 통제변수로 부모의 교육수준, 모의 취업여부, 가구의 자
녀수, 유아의 출생순위 및 연령, 거주지역이 포함되었다. 2단 계는 균등화가처분소득을 추가하였다.

1 단계의 경우 투입된 통제변수가 사교육비의 $9.5 \%$ 를 설명 하는 것으로 나타났으며, 이 모형은 통계적으로 적합하였다 $(F$ = 4.002, $p<.001)$. 아버지의 교육수준이 고졸일 경우, 대졸 이 상일 때와 비교할 때, 사교육비가 감소하는 것으로 나타났다 $(\beta=-.142, p<.05)$. 자녀의 연령이 높을수록 사교육비가 증가 하는 것으로 나타났다 $(\beta=.191, p<.001)$. 거주지역이 시 지역 인 경우보다 서울인 경우 $(\beta=-.158, p<.05)$, 군 지역인 경우보 다 서울인 경우 $(\beta=-.157, p<.05)$ 일 경우 사교육비가 증가하 는 것으로 나타났다.

Table 6

Hierarchial Multiple Regression Analysis: The Effects of Household Income on Preschool Childcare Expenses of 9th Year (2013) Data

\begin{tabular}{|c|c|c|c|c|c|c|c|}
\hline & Independent variables & \multicolumn{3}{|c|}{ Step 1} & \multicolumn{3}{|c|}{ Step 2} \\
\hline \multirow[t]{8}{*}{ Control variables } & Mother's employment dummy & .324 & .014 & .283 & -.155 & -.007 & -.133 \\
\hline & Father's middle school graduation dummy & -2.102 & -.038 & -.707 & -1.137 & -.021 & -.378 \\
\hline & Father's highschool graduation dummy & -.379 & -.016 & -.284 & .189 & .008 & .138 \\
\hline & Mother's middle school graduation dummy & -2.051 & -.034 & -.621 & -1.614 & -.027 & -.489 \\
\hline & Total number of children & -1.852 & -.152 & $-3.018^{* *}$ & -1.761 & -.145 & $-2.870^{* *}$ \\
\hline & Age of a child & .360 & .024 & .478 & .348 & .023 & .463 \\
\hline & Birth order & .080 & .014 & .281 & .149 & .026 & .521 \\
\hline & Metropolitan city dummy & -8.853 & -.318 & $-5.236^{* * *}$ & -8.591 & -.308 & $-5.082^{* * *}$ \\
\hline
\end{tabular}

Note. $\mathrm{Ln}$ is an abbreviation of natural $\log$.

${ }^{\mathrm{a}} 1$ = employed, $0=$ unemployed; $^{\mathrm{b}} 1=$ college graduate, $0=$ middle/high school graduate; ${ }^{\mathrm{c}} 1=$ Seoul, $0=$ metropolitan city $/$ county ${ }^{* *} p<.01 .{ }^{* * *} p<.001$. 
2 단계의 경우 투입된 독립변수가 사교육비의 $16.2 \%$ 를 설 명하는 것으로 나타났으며, 이 모형은 통계적으로 적합하였 다 $(F=7.877, p<.001) .1$ 단계에 비한 $R^{2}$ 증가량은 .091로 나타 나, 균등화가처분소득 투입으로 인해 사교육비에 대한 설명력 이 $9.1 \%$ 증가한 것으로 분석되었으며, 증가량은 통계적으로 유의하였다 $(F=42.274, p<.001) .1$ 단계와 마찬가지로 자녀의 연령이 높을수록 사교육비가 증가하며 $(\beta=.188, p<.001)$, 거 주지역이 시 지역인 경우보다 서울일 경우 사교육비가 증가하 는 것으로 나타났다 $(\beta=-.128, p<.05)$. 그러나 아버지의 최종 학력이 사교육비에 미치는 영향은 유의하지 않았다. 균등화가 처분소득이 증가할수록 자녀에 대한 사교육비가 증가하는 것 으로 나타났는데 $(\beta=.332, p<.001), 9$ 차 년도 사교육비에 대 한 회귀모형의 표준화된 $\beta$ 값과 5 차 년도의 표준화된 $\beta$ 와 비교 할 때 균등화가처분소득의 표준화된 $\beta$ 값은 소폭 상승한 것으 로 나타났다. 이는 균등화가처분소득이 보육비에 미치는 영향 이 5차 년도에는 유의하였다가, 9 차 년도에는 유의하지 않게 변화한 것과 상반되는 결과이다. 즉, 이러한 결과를 무상보육 정책 실시로 인하여 가구소득이 보육비에 미치는 영향력은 감 소하였으나, 사교육비에 미치는 영향력은 오히려 증가하게 된 것으로 해석할 수 있다.

\section{논의 및 결론}

이 연구에서는 정부의 보육비 지원 범위의 단계적 확대 과정 에서 나타난 유아 보육비 및 사교육비의 변화를 분석하고, 가 구소득 수준과 보육비. 사교육비 지출 변화의 관련성을 밝히 고자 했다. 이를 위하여 한국복지패널 자료를 이용하여, 무상 보육정책 실시 전후 시점인 2009년부터 2013년까지의 유아 보육비 및 사교육비 지출 변화의 경향성을 살펴보고, 그 경향 성이 가구소득 계층에 따라 어떠한 양상을 나타내는지 분석하 였다. 또한 2009년 무상보육정책 실시 전 가구소득이 보육비 와 사교육비에 미치는 영향력을 검증하고, 2013년 무상보육 실시 후에 그 영향력이 변화하였는지를 비교하였다. 이 연구 의 분석결과를 통해 아래 결론을 도출할 수 있다.

첫째, 무상보육정책 시행 전후의 유아 1 인당 보육비 및 사 교육비 지출액의 변화를 살펴보면, 보육비는 2010-2012년에 소폭 상승했다가 2013년에 하락하였으며, 사교육비는 20102012년에 소폭 하락했다가 2013년에 다시 상승한 것으로 나 타났다. 결과적으로는 2009년에 비하여 2013년에 보육비와 사교육비 지출 평균값이 다소 하락한 것으로 분석되었다. 이 는 여러 선행연구들과 마찬가지로 무상보육정책 시행 후 가구 의 보육비 및 사교육비 지출이 하락했다는 일관된 사실을 보

Table 7

Hierarchial Multiple Regression Analysis: The Effects of Household Income on Preschool Private Education Expenses of 9 th Year (2013) Data

\begin{tabular}{|c|c|c|c|c|c|c|c|}
\hline & \multirow[b]{2}{*}{ Independent variables } & \multicolumn{3}{|c|}{ Step 1} & \multicolumn{3}{|c|}{ Step 2} \\
\hline & & $B$ & $\beta$ & $t$ & $B$ & $\beta$ & $t$ \\
\hline \multirow{5}{*}{ Control variables } & Mother's employment dummy & 1.013 & .032 & .637 & -1.151 & -.036 & -.744 \\
\hline & Father's highschool graduation dummy & -4.703 & -.142 & $-2.531^{*}$ & -2.137 & -.065 & -1.182 \\
\hline & Mother's middle school graduation dummy & -4.809 & -.058 & -1.048 & -2.836 & -.034 & -.649 \\
\hline & Total number of children & -1.190 & -.071 & -1.394 & -.778 & -.046 & -.957 \\
\hline & Age of a child & 3.965 & .191 & $3.781^{* * *}$ & 3.908 & .188 & $3.923^{* * *}$ \\
\hline \multirow{3}{*}{ Household income } & Birth order & -.641 & -.082 & -1.620 & -.330 & -.042 & -.872 \\
\hline & Metropolitan city dummy & -6.095 & -.158 & $-2.592^{*}$ & -4.912 & -.128 & $-2.193^{*}$ \\
\hline & County ('gun') dummy & -8.671 & -.157 & $-2.527^{*}$ & -6.048 & -.109 & -1.841 \\
\hline
\end{tabular}

Note. $\mathrm{Ln}$ is an abbreviation of natural $\log$.

${ }^{\mathrm{a}} 1=$ employed, $0=$ unemployed; $^{\mathrm{b}} 1=$ college graduate, $0=$ middle/high school graduate; ${ }^{\mathrm{c}} 1=$ Seoul, $0=$ metropolitan city $/$ county ${ }^{*} p<.05 .{ }^{* * *} p<.001$. 
여준다(Y. J. Lee et al., 2013). 또한 보육비와 사교육비 지출액 변화 그래프가 서로 대칭적으로 변화하는 추세를 보였는데, 하나가 증가하면 다른 하나는 감소하는 제로섬(zero sum)의 관 계와 유사하다. 이는 보육비 지출과 사교육비 지출 변화가 서 로 역의 관계를 지닌다는 점에서, 무상보육정책으로 인해 사 교육비 지출이 증가할 수 있다는 주장(Min \& Bae, 2014; Suh et al., 2012)과 일치한다.

다음으로 가구의 보육-교육비의 실질적 부담 수준을 파악 하기 위하여 균등화가처분소득 대비 보육비 및 사교육비 지출 액의 변화를 살펴본 결과, 균등화가처분소득 대비 보육비.사 교육비가 모두 꾸준히 하락하고 있다. 이 양상은 유아 보육 및 교육비 지출로 인한 실제적 가계운용의 부담이 점진적으로 감 소했다는 것을 의미한다. 2009년 이후로 정부의 보육비 지원 혜택이 단계적으로 확대되어온 것을 고려할 때, 이러한 결과 는 보육비 지원 정책의 효과로서 유아 보육비·교육비 부담이 감소했음(Kim et al., 2013)을 의미한다.

이상 보육비 및 사교육비에 대한 분석결과를 종합하여 볼 때, 보육비 지원 정책은 가구의 보육-교육비 지출액이나 가구 소득 대비 부담 감소에 긍정적으로 작용함을 알 수 있다. 즉, 현 보육비 지원 정책은 가구의 아동 양육비 부담 감소라는 정 책 목표를 달성하고 있다. 그러나 보육비가 감소할 때 사교육 비는 증가하는 동반 경향을 볼 수 있다. 이 점을 고려한다면, 보육비 지원 정책이 단순히 자녀 양육비 지출 감소 외에 다른 측면에서 평가할 여지가 있다. 즉, 보육비 지원 정책이 단순히 보육비 및 사교육비 지출액을 변화시키는 작용뿐 아니라, 보 육비 지출을 변화시킴으로써 사교육비 지출도 연쇄적으로 변 화시킬 수 있는 역동을 만들어낼 수 있다는 것이다. 따라서, 만약 가구의 보육비 증감 추이만을 고려하여 보육비 지원 정 책을 평가한다면, 보육비 지원 정책이 야기한 자녀 양육비 변 화 역동의 제반 측면을 고려하지 못하고 보육비 지원 정책의 효과를 단순한 차원에서 과대평가할 수 있다. 이는 보육비 지 원 정책의 효과를 평가할 때, 보육비의 단순한 증감뿐만 아니 라 보육비 지출액 변화와 연동되어 나타나는 사교육비 지출 의 변동까지 포괄하여 다각적 차원의 평가가 필요하다는 점 을 시사한다.

둘째, 가구소득집단 구분에 따라 보육비 및 사교육비의 변 화 차이가 있다. 고소득 가구는 중. 저소득 가구보다 매우 높은 보육비 수준을 유지하다가 2013년에 중소득과 같은 수준으로 급락하는 양상이 나타난다. 이러한 현상은 무상보육정책 시행 의 결과, 이전에 보육비 지원을 받지 못했던 고소득층의 보육 비 부담이 대폭 감소되었다는 것을 보여준다. 보편적 복지정
책의 혜택이 중소득, 고소득층으로 귀착되는 결과로 나타날 수 있다고 주장한 Cho와 Yoo (2013)의 연구결과를 부분적으로 지지하는 것이다. 사교육비의 경우 2013년 무상보육정책 실 시 이후 고소득 가구와 저소득 가구의 사교육비가 함께 증가 한다. 이는 앞서 논의한 보육비와 사교육비가 가지는 역의 관 계성이 적용되는 대목으로 보육비 지원금이 사교육에 재투자 될 수 있다는 연구결과(Min \& Bae, 2014; Suh et al., 2012)와 일 치한다. 다만 선행연구에서는 주로 고소득층을 중심으로 보육 비 지원금이 사교육비에 재투자되는 현상만을 보고했으므로 (K. S. Lee \& Kim, 2010) 앞으로 저소득 가구가 특히 보육비 지 원 정책의 민감하게 반응하는 원인에 대해서는 후속연구에서 더욱 심층적으로 다뤄질 필요가 있음을 제안한다.

다음으로 보육비 및 사교육비의 가구소득 대비 부담 수준 의 변화가 가구소득 구분에 따라 차이가 있는지에 대해서 살 펴본 바, 균등화가처분소득 대비 보육비 및 사교육비 변화 경 향은 소득계층 별로 다른 변화 경향이 있다. 중·고소득 가구 의 경우 2009년부터 2013년까지 일정한 수준을 유지하였지 만, 저소득가구는 2009년 보육비와 사교육비가 중·고소득 가 구보다 높을 수준을 나타내고 2010년에는 그 수치가 급격히 상승하였다. 이는 보육비 지출이 가처분소득에 대비하여볼 때, 중·고소득 가구보다 저소득 가구에 상대적으로 높은 부담 으로 작용함을 의미한다. 2011년 0-5세 가구 소득하위 70\% 대 상 보육비 전액지원이 실시되면서 저소득 가구의 가처분소득 대비 보육비와 사교육비가 모두 급격하게 감소한다. 이 사실 은 저소득층에서 보육·교육비 지원으로 인한 가계경제 도움 정도를 가장 높게 체감했다는 Y. J. Lee 등(2013)의 연구결과와 는 일치했지만, 보육비 지원 정책의 혜택이 중산층에서 가장 컸다는 Hong (2013)의 연구결과와 무상보육정책 시행으로 인 한 가구소득 대비 보육비 감소폭이 저소득가구보다 일반가구 에서 더 컸다는 K. I. Kim (2014)의 연구결과와는 차이가 있다. 이 연구에서는 보육비 지원 정책이 상대적으로 자원이 부족한 저소득 가구에 중요한 유아 보육·교육비 지출부담 경감 요인 으로 작용할 수 있다는 사실을 제시한다.

이상 소득계층별 보육비 및 사교육비 변화 및 가구소득 대 비 보육비 및 사교육비 수준에 대한 결과를 종합하여 볼 때, 전 계층을 대상으로 한 보육비 지원의 혜택은 고소득층에게 돌아 갔음을 알 수 있다. 전 계층 무상보육정책 실시 이전에도 이미 소득분위 하위 $70 \%$ 가구를 대상으로 보육비 지원이 이루어지 고 있었기 때문에, 2012년 누리과정 도입 및 2013년 5세 이하 무상보육정책 도입은 소득분위 상위 $30 \%$ 를 위한 것이었다고 할 수 있다. 이는 2013년 고소득 가구의 보육비가 중소득 가구 
수준으로 급격하게 감소한 점, 그리고 2013년 가처분소득 대 비 보육비 지출 수준이 고소득층에서 가장 낮게 나타난 점에 서 확인할 수 있다. 저소득 가구가 보육비 지원을 받음으로써 가장 많은 보육비 및 사교육비 부담 경감을 경험한다는 점을 고려할 때, 이러한 결과는 보육비 지원 정책이 보육비 및 사교 육비 부담 경감 완화의 효율성을 높이기 위해서는 저소득 가 구에 대한 집중적인 지원이 필요하다는 것을 의미한다.

또한 전 계층 보육비 지원 정책 결과, 고소득 가구의 보육비 를 감소하였을 뿐만 아니라 사교육비도 함께 증가하였다. 즉, 무상보육정책은 고소득 가구의 보육비 부담을 감소시킨 것에 서 그치지 않고 사교육비 지출을 증가시켜서, 결과적으로 중. 저소득 가구와의 사교육비 지출 격차가 증가하는 양상이 동시 에 나타난다. 이는 소득 계층과 무관한 영유아의 평등한 출발 선 제공을 목표로 하는 무상보육정책이 오히려 사교육의 측면 에서는 소득 계층 간 격차를 유발시킬 가능성이 있음을 보여 준다. 따라서 사교육비의 측면에서 보육비 지원 정책이 영유 아 보육·교육의 소득계층 간 격차를 줄이고 재분배효과를 제 고하기 위해서는, 정책 대상 범위를 적정한 수준으로 한정하 거나 가구의 소득수준에 따라 차별적인 지원이 이루어질 필요 성이 있다.

셋째, 보육비 및 사교육비 관련 변인들의 영향력을 통제한 상태에서 가구소득이 무상보육정책 실시 전과 후에 보육비와 사교육비에 미치는 영향을 분석한 결과, 가구소득은 무상보육 실시 전에 보육비와 사교육비에 정적인 영향을 미치는 것으 로 나타났으나, 무상보육 실시 후에는 균등화가처분소득이 보 육비에 미치는 영향은 사라지고 대신 사교육비에 미치는 영향 이 소폭 증가한 것으로 나타났다. 즉, 보육비의 경우 무상보육 정책 실시 전에는 가구소득이 증가하면 보육비 지출도 증가하 는 경향을 나타내다가 무상보육정책 실시 후에는 이러한 경향 이 나타나지 않았다. 반면 사교육비의 경우 무상보육정책 실 시 전후 시점에서 모두에서 가구소득이 증가하면 사교육비 지 출이 증가하는 관계를 가지며, 이러한 관계성은 무상보육정책 시행 이후 더욱 강화된 것으로 나타났다.

무상보육정책실시 전의 결과만을 고려할 경우 이는 가구소 득이 높을수록 미취학 자녀의 보육비 및 사교육비가 증가한 다는 선행연구와 일치한다(Suh \& Yang, 2013). 그러나 무상보 육정책 실시 후의 결과에서는 이는 무상보육정책 시행 후 소 득계층에 무관한 보육비 전액 지원이 이루어짐에 따라 가구 소득이 보육비 지출에 미치는 영향력은 감소하지만 한편으로 는 가구소득이 사교육비에 미치는 영향이 더 높아지는 현상을 보여준다. 즉, 무상보육정책이 유아 보육, 사교육 비용 및 소
득 대비 부담액 감소에는 기여하였지만, 소득계층 간 보육·교 육비 지출격차를 완화했다고 평가하는 데에는 한계가 있음을 의미한다. 이는 무상복지 정책의 혜택이 고소득층이나 중산층 의 사교육 증가현상을 가져왔음을 시사한다. 따라서 유아 보 육 및 교육에서 소득계층 간 보육·교육비 지출의 격차감소를 위해서, 소득계층에 따른 사교육비 지출 차이가 중요한 요인 으로 다뤄져야할 필요가 있다. 앞서 논의한 바와 같이 무상보 육정책이 실제적으로 가구의 소득수준과 상관없이 모든 영유 아에게 평등한 교육기회를 제공하고자 한다면, 보육비 지출의 변화가 사교육비 지출 변화에 미치는 영향이 소득계층별로 다 른 양상으로 나타나며, 이에 따라 소득계층 간 사교육비 격차 변동에까지 영향을 미칠 수 있다는 점을 고려할 필요가 있다.

이 연구는 다음과 같은 이론적·실천적 함의를 가진다. 첫 째, 무상보육정책 시행 과정에서 나타난 보육비와 사교육비의 변화를 살펴보았다. 특히 무상보육은 보육비 관련 문제이지만 보육과 사교육 간 선택이라는 관점에서 무상보육정책이 유아 자녀를 둔 자녀를 둔 가정의 사교육 지출에 영향을 미칠 수 있 다는 것을 확인하였고, 더 나아가 소득집단별로도 다른 양상 을 보임을 밝혔다. 이로써 국가의 제한적인 보육 예산의 범위 내에서 예산을 효과적으로 사용하기 위해서는 보육비 지원 대 상의 범위를 한정하거나, 소득계층에 따라 보육비 지급액이 달라질 필요가 있음을 제안한다.

둘째, 무상보육이 보육비나 사교육비 변화에 어떠한 영향 을 미치는지 밝히는 것에서 더 나아가 가처분소득 대비 보육 비 및 사교육비가 차지하는 비율을 살펴봄으로써 실질적으로 가계경제운용에서 부담의 변화를 알 수 있었다. 보육비 지원 정책으로 인한 실질적인 가계경제운용에서의 보육비 및 사교 육비 완화 효과는 저소득 가구에서 가장 높게 나타났으므로, 보육비 지원에서 저소득층 지원이 우선시될 필요가 있다.

셋째, 무상보육정책이 가계경제에 이바지하고 보육비 경감 을 통한 출산율 제고에 기여하는 측면도 있으나, 오히려 사교 육비 지출의 계층 간 격차를 심화시킬 수 있다는 점에서 국가 보육정책에 요구되는 가치인 보육 및 교육의 공공성 강화와는 배치될 수 있음(Rhee, 2010)을 확인하였다. 또한 사교육비 지 출의 계층 간 격차는 자녀양육비에 대한 경제적.심리적 부담 을 가중시킬 수 있으므로, 무상보육정책에 대한 검토를 진행 할 때 사교육비 지출의 계층 간 격차 완화에 대한 정책적 고려 가 필요함을 제안한다.

이 연구의 제한점 및 후속연구 제언은 다음과 같다. 첫째, 무상보육정책의 효과를 비교함에 있어서 패널 데이터 변수의 한계로 인해 보육비와 사교육비 지출에 한정된 논의를 진행하 
였다. 경제적 차원을 평가하기 위해서는 보육비, 사교육비뿐 만 아니라 더 포괄적인 자녀양육비를 살펴볼 필요가 있으며, 경제적 차원에서의 효과뿐 아니라 심리, 발달적 차원에서의 효과를 평가하기 위해서는 부모의 만족도나 영유아의 발달적 결과를 함께 고려한 후속연구가 필요할 것으로 생각된다.

둘째, 저소득층 및 차상위층 가구에 보육료가 지원되기 이 전 시점을 포괄하지 못한 한계가 있다. 우리나라는 1992년부 터 저소득층 아동에 대한 보육료 지원이 시작되었고, 2006년 부터 차상위계층에 보육료 전액 지원이 시작되었다( $\mathrm{MOHW}$, 2013). 보육료 지원 정책 확대의 중요한 시점들을 포괄하여 보 육비 및 사교육비 지출의 변화를 소득계층별로 살펴보는 후속 연구가 필요할 것이다.

셋째, 보육시설 및 사교육기관의 다양한 유형별 특성이 고 려되지 못하고, 단순하게 보육비 및 사교육비 전체 금액의 합 으로 측정하였다는 점에서 한계점이 있다. 보육시설의 경우 민간어린이집, 국공립어린이집, 직장어린이집 등 다양한 유형 이 존재하며, 유아 사교육의 경우에도 특별활동, 학습지, 과외, 어학원, 돌봄교사 활용 등 다양한 유형이 있다. 이와 같이 보육 시설 종류 및 사교육의 종류에 따른 고유한 특성 차이가 있기 때문에, 이를 반영하여 유형별 보육시설 및 사교육기관의 사 교육비와 보육비, 그리고 가구소득 간의 연관관계를 살펴보는 연구의 필요성을 제시한다.

\section{Note}

This article was presented at the 2015 Annual Fall Conference of the Korean Association of Child Studies.

\section{Conflict of Interest}

No potential conflict of interest relevant to this article was reported.

\section{References}

Baek, S. H., \& Cho, S. W. (2005). The determining factors of expenditure levels for daycare and education services for families with pre-school children. The Korea Association of Child Care and Education, 41, 429-455.
Branscomb, K., \& Goble, C. (2011). An exploration and comparison of infant feeding practices in home and center contexts. Child Studies in Diverse Contexts, 1(1), 39-49.

Castles, F. G. (2010). The Oxford handbook of the welfare state. Oxford University Press.

Cha, S. H., Kim, S. N., Kim, J. K., Park, S. W., Jeon, K. W., Min, B. C., \& Choi, B. Y. (2010). An analysis of supplemental education and its influence in early childhood education (Research Report 2010-33). Seoul, Korea: Korean Educational Development Institute.

Cho, K. Y., \& Yoo, J. S. (2013). Redistributive effects of free welfare (Research Report No. KERI Insight 12-09). Seoul, Korea: Korea Economic Research Institute.

Hong, J. L. (2013). The analysis of the effectiveness of governmental child-care subsidies. Korea Journal of Population Studies, 36(4), 95-118.

Jung, M. Y. (2012). Research on the effect of child-care facilities management by child care cost support policy (Unpublished master's thesis). Chonnam National University, Gwangju, Korea.

Kim, J. K. (2004). The factors that decide pre-school children's using and expenditure of private education. Journal of Consumer Studies, 15(3), 67-86.

Kim, J. S. (2014). Childcare center parents' and director's recognition of childcare service after implementation of free childcare policy (Unpublished master's thesis). Kwangwoon University, Seoul, Korea.

Kim, K. I. (2014). The influence of expansion in childcare subsidy on relieving the burden of child-rearing and women's economic activity participation: Focusing on difference of income bracket (Unpublished master's thesis). Sungkonghoe University, Seoul, Korea.

Kim, M. S., Jun, J. A., Ha, T. J., Kim., H. J., Oh, M. A., Jung, U. H., . . Kim, S. S. (2013). General survey on child status (Policy Report No. 2013-92). Sejong, Korea: Korea Institute for Health and Social Affairs.

Kim, S. H., Joo, E. S., \& Hong, G. Z. (2013). An analysis on key stakeholders' preference on free child care and related policy issues: Focused on the directors and workers of child care center, and parents in Seoul. Social Welfare Policy, 40(2), 205-235.

Ku, I. H., Son, B. D., \& Ahn, S. H. (2010). Social welfare policy. Paju, Gyeonggi: Nanam.

Kwon, K. L. (2011). (The) use and cost of private tutoring for young children in Korea (Unpublished master's thesis). Sungkyunkwan University, Seoul, Korea.

Lee, K. S., \& Kim, J. H. (2010). Analysis of private tutoring expenses for young children by family characteristics. Journal of Future Early Childhood Education, 17(1), 21-38.

Lee, S. L. (2011). Consumption of child care and education 
services in the households with preschool children. Journal of Human Life Sciences, 14, 117-134.

Lee, Y. J., Lee, J. W., \& Kim, M. J. (2013). An analysis of change in household expenditure on childcare and education with the introduction of 'Nuri Curriculum' subsidies in 2012. Journal of Child Care and Education Policy, 7(2), 166-189.

Min, S. O., \& Bae, J. H. (2014). Mothers' perceptions of and experiences about children's private education. The Korean Journal Child Education, 23(4), 263-285.

Ministry of Health and Welfare. (2013). 2013 Ministry of Health and Welfare fund management plan outline budget and jurisdiction. Sejong, Korea: Ministry of Health and Welfare.

Rhee, O. (2010). A critical review on the performance and changes of child care policy in Korea. Korean Journal of Child Studies, 31(1), 197-217.

Statistics Korea. (2015a). Final results of birth statistics in 2014. Daejeon, Korea: Author. Retrieved from http://kostat. go.kr/

Statistics Korea. (2015b). Household Income \& expenditure trends in the first quarter 2015. Daejeon, Korea: Author. Retrieved from http://kostat.go.kr/

Suh, M. H, \& Yang, M. S. (2013). An analysis of private learning expenses of young children and its determining factors. Journal of Korean Child Care and Education, 9(3), 189-207.
Suh, M. H., Yang, M. S., \& Son, C. K. (2012). Research on estimation of early childhood care and education cost and countermeasures (Reserach Report No. 2012-11). Seoul, Korea: Korea Institute of Child Care and Education.

Yang, M. S. (2013). Changes in preschoolers' private education spending caused by expansion of childcare and education expenses subsidy (Issue Paper No. 2013-16). Seoul, Korea: Korea Institute of Child Care and Education.

$\begin{array}{ll}\text { Su-Ji Jung } & \text { http://orcid.org/0000-0001-8121-3638 } \\ \text { Yun-Hyun Pack } & \text { http://orcid.org/0000-0001-6956-2325 } \\ \text { Ji-Na Song } & \text { http://orcid.org/0000-0002-2492-0472 } \\ \text { Daewoong Kim } & \text { http://orcid.org/0000-0001-9393-4424 } \\ \text { Soon-Hyung Yi } & \text { http://orcid.org/0000-0002-3381-1788 }\end{array}$

Received November 30, 2015 Revision received January 17, 2016 Accepted February 1, 2016 